\title{
THE CHANGING FACE OF BURNS ${ }^{\dagger}$
}

\author{
J. W. VAN DER SPUY, M.B., B.Ch., F.C.S. (S.A.)*
}

\begin{abstract}
Oorsig van nuwe verwikkelinge in die behandeling 'n Oorsig vandwo word gegee. Gespesialiseerde eenhede wh brandiese behandeling in isolasie moontlik is en wiar asepig in die ontwrigte fisiologie as gevolg van beter insig-trauma is verantwoordelik vir die verbeterde brandwond vir brandwond-pasiënte. Effektiewe vloeistofprognose gedurende die skokfase; die instelling van hiperteraple gedie; hernude belangstelling in die lokale letsel; dinentasie; hernude belangstelling in die lokale letsel; verbeterde verloorplandwonde as gevolg van elektrisiteit; in gevalle met brandwonde as gevolg van elektrisiteit; die belang die gebruik van eskarotomie word kortliks beskade en Die belang van goeie eerstehulp behandeling spreek. beklemtoon.
\end{abstract}

One hundred years ago the fate of a severely burnt patient was a dismal one. At that time important breaknoughs were being made in many fields of surgical endeavour. Lister's work on asepsis had made its impact and rocked the surgical world. Sepsis had to be prevented. Burn cases were an important source of sepsis and they were consequently moved out of the teaching hospitals to quieter bywaters like the Janitor's House in Edinburgh. In these places they pursued their pitiful course of pain, sepsis, and often death. Mortality was high and morbidity lamentable.

This century saw the progressive advent of intravenous fluid therapy resulting in a marked decrease in mortality. Skingrafting techniques were improved and a second appreciable decrease in mortality occurred when better topical applications which could penetrate the slough came on to the market. This improved the outlook for the burnt patient. Nevertheless, as recently as 20 years ago, the statement was made that the mortality in large burns equated roughly to the percentage of body surface that had been burnt, indicating that a $60 \%$ burn had an expected mortality risk of $60 \%$.

Since then major advances have been made, many of hem in the last decade. Figures for mortality and morbidity decreased markedly and the Red Cross Memorial Hospital has recorded an annual mortality of $0,7 \%$ for complicated paediatric burns admitted to its Burn Unit, while the teaching hospitals of Witwatersrand University have halved the hospitalisation time for severe burns from 5 weeks to $2 \frac{1}{2}$ weeks.

What brought about this change in prognosis in recent years? As I see it, two factors have been responsible:

A. The establishment of specialised burn units where patients can be managed aseptically and in relative or complete isolation.

B. Better understanding of the deranged physiology following major burn trauma, with therapeutic measures geared accordingly.

$\dagger$ Paper presented at Post-registration Course preceding the 12th National Council Meeting of the South African Society of Physiotherapy, May 1977.

"Senior Surgeon, Accident Unit, Groote Schuur Hospital, Cape Town and Department of Surgery, University of Cape Town.
Certain aspects of management that have undergone change or that have received new emphasis in recent years will be discussed briefly, as these form the basis of current burn therapy.

Intravenous fluid therapy in the shock phase:

The large burn loses vast amounts of fluid and plasma protein from the surface and this is lost to the body. The loss goes further however. The fluid is also sequestrated into the tissues deep to the burnt skin in the form of oedema fluid. Should the patient become severely shocked and acidotic, further intricate fluid shifts may occur into healthy tissues throughout the body and lead to additional loss of intravascular volume and electrolyte disturbances. Red blood cells are damaged in two ways: some are trapped and burnt in the damaged areas; others are thermally damaged less critically, weakened and subsequently removed from the circulation and broken down by the body. This results in anaemia, usually manifest a few days after the burn.

Until recently these changes were combated by the use of "thick fluids" like plasma and blood during the shock phase, which lasts for at least the first 24 hours. The rationale was replacement of the plasma and red cell loss. This tended to cause a blood of high viscosity which did not circulate optimally through the constricted capillaries of the shocked patient. There was also often a delay in resuscitation while one was waiting to obtain plasma and blood, thus aggravating shock.

The tendency now is to start intravenous therapy with balanced salt solutions like Plasmalyte $\mathbf{B}$ and Ringer lactate, which are immediately available and more physiological. They appear to promote better circulation through the narrowed capillaries and promote early and adequate urinary output. If necessary, acidosis is treated with intravenous sodium bicarbonate. Plasma and blood are used subsequently when necessary, i.e, they are used more and more in the second round of the fight rather than the first.

\section{The advent of hyperalimentation:}

The patient with a large burn requires up to three times the normal caloric intake to maintain normal function in the face of a markedly raised basal metabolic rate. Normal diet and the customary intravenous fluids cannot supply the need. This produces a state of relative starvation and the patient loses weight, as he utilises his body proteins as energy substrate. The end result is often a wasted patient with low resistance to infection and poor response to skingrafting procedures. Even ten years ago these cases could be seen in most hospitals.

Hyperalimentation basically means the supplementation of ordinary caloric intake by the administration of special high-calorie substances. There are two types of hyperalimentation, oral and intravenous.

In oral hyperalimentation the patient can take an ordinary diet but this will not provide adequate calories. In these cases the patient is given a high protein, high carbohydrate diet and to this is added as many eggs as possible as well as additives like Caloreen. One egg contains 60-70 calories and is also high in protein content. In this way one can easily double the caloric intake.

Intravenous hyperalimentation is used on patients who are unable to take food by mouth. It can also be used as a supplement to oral feeding. Ordinary intravenous fluids are low in caloric content and consequently fluids like Amigen and Intralipid are used, containing protein and lipid concentrates. Concentrated dextrose solutions 
can also be used but must be given by a central venous catheter because peripheral veins are sclerosed. Longterm intravenous hyperalimentation is technically complicated and is not without side-effects.

What hyperalimentation has achieved is to keep the patient with a large burn in nutritional balance and to prevent the wasting and protein depletion that occurred in the past.

\section{Renewed interest in the local lesion:}

Until recently the emphasis in burn management was on fluid therapy. Sloughs were removed by dressing techniques which usually took about three weeks. Then the granulating defect was covered with skingraft.

Over the last few years there has been a renewed interest in the local lesion for two reasons:

Slough tends to have an adverse effect on viable skin cells lying below the slough, and in this way a partial-thickness burn may be rendered fullthickness.

In addition slough tends to get infected. This sepsis puts an added strain on the patient, may delay grafting and can cause septicaemia.

This concept gave rise to two important developments:

1. Better topical applications were developed which can penetrate into the slough and have good antibacterial properties, e.g. Mafylon, Flamazine and Betadine.

2. Early surgical desloughing of dead tissue was followed by skingrafting. The early results of this are promising as it minimises sepsis and also provides early skin cover, thereby decreasing hospitalisation time. Theoretically this should be done in the acute phase but we prefer to wait until after the fifth day when the patient is metabolically stable.

\section{Improved techniques in skingrafting:}

It is now established that one needs more than good technique for optimal results in skingrafting procedures - the patient and the recipient area should be wellprepared. The nutritional state, haemoglobin level and bacteriological state must be adequate and the granulations healthy and free of beta-haemolytic streptococci. Once this point has been reached the scene is set for a good result and additional techniques become important in achieving full "take" of a graft:

1. We almost routinely use meshed skin because the multiple perforations allow secretions to drain rather than to lift the graft off its bed. This has improved graft "take" considerably.

2. In grafting large areas it is best to take enough skin to cover about $10 \%$ of the body surface area, process and apply it and dress the area concerned. Then the process is repeated for another similarly-sized area until the wound has been covered. This staggers the blood loss and also allows one to terminate the procedure at any stage should the patient become too cold from exposure; heat loss from granulating areas can be considerable in small children in a cool theatre.

3. The use of biological dressings like cadaver skin, pigskin and human amnion has proved valuable in providing temporary cover in large burns where the patient's own undamaged skin is not adequate in size to allow skin grafting in one session. They are also useful in clearing sepsis from granulating areas.

\section{Better appreciation of electrical burn problems:}

What matters in an electrical burn is not the skin damage (which is usually localised) but the damage done to the subcutaneous structures through which the current is conducted. The crux is that skin damage may be insignificant and yet the deeper tissues can be exten- sively damaged. Current follows the path of least re. next along blood vessels and ultimately via musc nerves. Skin has a high electrical resistance, thus explaininge it is not often involved between entrance and exing why

Any patient with any electrical burn should poinis mitted and observed for at least 24 hours, he ad. insignificant the injury looks initially. Especially injury was due to a high-tension current, he need surgery to decompress muscle compartment well resect dead muscle. He may also develop shock haemoglobinuria and renal failure. It is to be noted that the extent of damage of ten only
becomes apparent after a few hours.

\section{Greater awareness of associated respiratory damage:}

Damage to the airway and lungs must be susnected in any patient with flame burns especially if the burn occurred in an enclosed space where fumes from burnin paint, etc., could have been inhaled in addition to hot air. The risk rises if the face itself was burnt and rises even further if the insides of the nostrils and the rises hairs have been damaged. If bronchospasm, stridor of copious airway secretions are also present, the diagnowis is virtually made. Restlessness and anxiety (due t) hypoxia) may be the first indication of respiratory damage, however, and in this type of case blood gas analysis is essential. It should be emphasised that the initial chest radiograph is usually normal as the radiological changes take 12-24 hours to develop. A normal chest radiograph in the early phases does not exclinge the condition.

A severe, rapidly progressive bronchopneumonia soon develops and unless early and expert respiratory care is given the pulmonary damage is often fatal. This is one of the phases of burn mortality which has undergone a considerable change as a result of the advent of Respiratory Intensive Care Units in our big hospitals. Almost half of these patients now survive.

The essence is to suspect and diagnose respiratory damage as soon as possible so that effective management can start early.

\section{The free use of escharotomy:}

Full-thickness burnt skin contracts. If the burn is circumferential on the trunk a tourniquet type of constriction can be caused, producing respiratory restriction. In the limbs, circulatory embarrassment can be caused in a similar way.

In such cases it is most important to decompress the part concerned by incising the burnt skin (eschar) longitu dinally. The edges will separate and the compression is relieved. The procedure is painless as the dead skin is insensitive.

Many digits, limbs and patients have probably beell saved by this simple measure.

\section{New techniques to minimise scar formation and contracture:}

Proper positioning of the burnt patient, together with early and adequate movements, elevation of the burnt part, good grafting technique and compressive therapy to minimise scar hypertrophy have been reviewed in this Journal by $H$. Maxwell and by Susan Keays ( 1 and 2).

\section{Adequate first-aid measures:}

Good first-aid management is most important. The basic rules are:

1. Remove the damaging agent. Wash chemical burns with running water; in flame burns, wrap the person in a blanket to extinguish the flames and then remove the blanket and clothes so that the heat can dissipate; if clothes are alight, get the patient to lie down to save his face and lungs - flames spread upwards.

Continued on page i? 